Waste and Resource Management Volume 168 Issue WR4

Europe's waste incineration capacities in a circular economy

Wilts and von Gries

ice | proceedings
Proceedings of the Institution of Civil Engineers

Waste and Resource Management 168 November 2015 Issue WR4

Pages 166-176 http://dx.doi.org/10.1680/warm.14.00009

Paper 1400009

Received 08/07/2014 Accepted 20/02/2015

Published online 23/05/2015

Keywords: infrastructure planning/recycling \& reuse of materials/

waste management \& disposal

ICE Publishing: All rights reserved

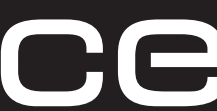

nstitution of Civil Engineers

\title{
Europe's waste incineration capacities in a circular economy
}

1 Henning Wilts $\mathrm{PhD}$

Research Fellow and Project Coordinator, Research Group Material Flows and Resource Management, Wuppertal Institute for Climate, Environment and Energy, Wuppertal, Germany
2 Nadja von Gries MSC

Research Fellow, Research Group Material Flows and Resource Management, Wuppertal Institute for Climate, Environment and Energy, Wuppertal, Germany
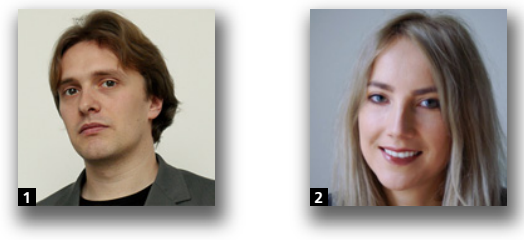

A lack of proper treatment infrastructure and sufficient capacity for municipal solid waste (MSW) treatment is a crucial barrier for the environmentally sound management of waste. However, overcapacities, especially for waste incineration, also have to be taken into account regarding their potential impacts on recycling markets and waste treatment prices. This paper provides a comprehensive overview of existing MSW incineration plants and their capacities within Europe. In combination with the analysis of imports and exports of MSW for incineration, it provides an indication of over- and undercapacities for incineration plants. Among other things, the results show that in six of the 32 countries analysed in this study, capacities exceed more than $50 \%$ of the annual waste generation, while in two countries the total amount of waste generated annually is not enough to fill all the incineration plants.

\section{Introduction}

\subsection{Relevance of waste management capacities in a circular economy}

According to the Roadmap to a Resource Efficient Europe, the European Union (EU) should achieve a situation whereby waste is managed as a resource by 2020 (EC, 2011). This seems extremely ambitious considering that 19 of 32 countries in Europe still landfill more than $50 \%$ of their municipal solid waste (MSW) and only 16 of the 32 countries recycle more than $25 \%$ (EEA, 2013a). Nevertheless, in some member states, more than $80 \%$ of the waste is already recycled, indicating the possibilities of using waste as one of the EU's key resources.

Achieving a European circular economy requires nothing less than a radical transition of the waste management sector that, for many years, has focused on the reliable and cheap disposal of waste and on reducing environmental pressures from disposal (EMAF, 2012; Wilts, 2014). It is only recently that waste is no longer seen as something to get rid of, but as a potential secondary resource. Against this background, technical infrastructure systems for waste management, such as plants for the sorting and recycling of waste, can be seen as key catalysts for sustainable development (Monstadt, 2009). In many ways they determine the direction and magnitude of material flows and thus on the one hand cause environmental pressures and on the other help to solve urgent problems caused by the increasing use of resources in Europe (Monstadt et al., 2012). Nevertheless, technical infrastructure systems and their impacts on consumption patterns or eco-innovation trajectories are often overlooked, rendering them 'the forgotten, the background, the frozen in place' (Star, 1999). This is especially true when it comes to waste incineration capacities that often make recycling economically unattractive and clearly lower the incentives for preventing waste in the first place (Wilts, 2014).

The goal of the EU to become a 'circular economy' demands new requirements (in the waste framework directive (WFD)) for the planning of such infrastructure systems. Based on the principle of proximity, article 16 of the WFD requires the establishment of an integrated and appropriate network of waste treatment facilities on a national level. However, the revised directive also opens the door to a European waste market, since it states that this network 'shall be designed to enable the community as a whole to become self-sufficient in waste disposal as well as in the recovery of waste' (EC, 2008: article 16). 
To meet these regulations, the concept of a circular economy still raises a variety of questions, especially with regard to the incineration of waste. It seems clear that on the path to a circular economy that feeds waste back into the economy as a raw material, much higher priority needs to be given to material recycling (Dehoust et al., 2014; Scheelhaase et al., 2008; Wilts, 2013). The Roadmap to a Resource Efficient Europe states that by 2020 only non-recyclable waste should be incinerated (EC, 2013b) - indicating that waste incineration will still have an important role to play in the European waste management system, especially when it comes to the disposal of hazardous waste (O'Donovan and Collins, 2011). This paper aims to support a discussion about how much waste incineration might be necessary and at the same time to consider how these capacities might even be a barrier to further recycling (Sahlin et al., 2007).

\subsection{Risk of over- and undercapacities}

Although the WFD obligates all member states to develop waste management plans in order to ensure that sufficient capacities are in place, a study published by the EC in 2012 states that, for some member states, undercapacities most likely exist with regard to the requirements set in the WFD (BiPRO, 2012). Post-consumer recycling capacities in particular (and sometimes even technologies) are not in place for certain rare metals such as silver, indium, rhenium and tungsten, which are present in various waste streams (BIO IS, 2011a).

Overcapacities, especially for waste incineration, also have to be taken into account because they have potential impacts on the recycling market and on waste treatment prices (Alwast, 2014). On a global level, the thermal recovery of MSW is growing continuously (Jafra Sora, 2013). Between 2007 and 2013, nearly 300 new incineration plants were constructed and technical capacities have increased by $25 \%$ up to more than $250 \mathrm{Mt}$ per year (Döing and Loenicker, 2013). On the European level, the recently published green paper on plastic waste describes a 'vacuum cleaner effect' (EC, 2013a) in favour of waste-to-energy as one of the most relevant barriers for material recycling that, from a resource efficiency point of view, would clearly be superior to waste incineration.

Against this background, this paper presents updated results from a recently completed study on the availability of waste treatment capacities in Europe for municipal waste funded by the European Environment Agency (EEA) in the context of the European Topic Center on Sustainable Consumption and Production (Wilts and von Gries, 2014). Section 2 describes the research procedures and scope of the paper. Section 3 provides a complete overview of existing municipal waste incineration plants and their capacities within the EU; in combination with an analysis of imports and exports of municipal waste for incineration, it provides an indication of over- and undercapacities for incineration plants. These results are discussed in Section 4. Based on these empirical findings, Section 5 describes the initial elements of an integrated approach to waste capacity planning that takes into account future potential for prevention and recycling.

\section{Methodology}

This paper focuses on waste incineration plants that are technically and legally suited to treating mixed MSW (household waste and similar commercial, industrial and institutional waste according to the European waste catalogue) without any pretreatments. Accordingly, this study only covers waste-to-energy plants (R1 treatment operation according to the WFD) and MSW treatment in incinerators without R1 standard (D10 treatment operation according to the WFD), but excludes coincineration plants and refuse-derived fuel (RDF) plants. The scope of the paper is thus based on a public waste management planning perspective. Nevertheless, RDF plants are an increasingly important factor, especially when it comes to the analysis of imports and exports of waste for incineration (see Section 4).

\subsection{Incineration capacities}

Despite the risks of under- or overcapacities as described in Section 1.2, so far, the level of information about the current utilisation of waste management capacities and the absolute number of available treatment capacities is more than deficient. In particular, differentiation of the capacity according to type of waste poses a challenge. In the statistics, the treated waste is subdivided by type of waste but the total plant capacity is not usually documented by the different waste inputs (identifying the share of MSW and non-MSW for the plants could be problematic). Moreover, it is often unclear whether approved or usable capacities are stated. Certain technical factors can influence plants' capacities, leading to variations in capacities (Richers, 2010). Nevertheless, this research drew upon a variety of studies and sources that provide information on specific treatment capacities or waste streams, although so far they do not add up to a coherent picture. The main sources for data on the availability of waste incineration plants and their capacities are statistical data from Eurostat (2012a, 2012b, 2013), Confederation of European Waste-to-Energy Plants country reports (CEWEP, 2010), EEA country reports (EEA, 2013b), the Waste-to-Energy State-of-the-Art Report (ISWA, 2012), Screening of Waste Management Performance of EU Member States (BiPRO, 2012), national waste management plans, environmental agencies, plant operators' webpages and other internet sources. The specific sources for capacities and locations of the single incineration plants can be found in the underlying study (Wilts and von Gries, 2014).

\subsection{Import and export of waste for incineration}

In order to analyse import and export waste flows, this study used data provided by Eurostat. Eurostat performs quality 
checking of the data, including checking the compatibility of what is reported as an import by member state 1 and the corresponding export by member state 2 (Fischer, 2012). On that basis, Eurostat data are preferred over the data reported by countries to the Basel Convention secretariat (Basel Convention, 2011).

Eurostat provides data showing the category and disposal method of waste exported and imported per country. Regarding the classification of the types of waste listed in annex 1 of the Basel Convention on the control of transboundary movements of hazardous wastes and their disposal, two categories (with regard to the incineration plants under consideration) are relevant for this study

- Y18 - residues arising from industrial waste disposal operations

Y46 - wastes collected from households.

Waste classified as Y18 covers both waste from municipal sources and from other sources, and no information is available for the share of municipal waste derived residues. These aggregated $\mathrm{Y}$ codes, which include many different waste types (in the same $\mathrm{Y}$ code) are one of the main reasons why the quality of data on waste shipments within or out of the EU can be classified as poor (Fischer et al., 2012a). Differentiating between these waste streams by type of incineration operation (D10 or R1) is not possible. This therefore has an inevitable impact on data quality. Figure 1 illustrates the data situation and the analytical framework for analysing imports and exports in this study.

\section{Results}

\subsection{Waste incineration capacities in Europe}

According to the scope of this analysis, the total number of incineration plants in EEA member countries is 450 (Turkey is excluded due to lack of data). This amounted to a total incineration capacity of $73747428 \mathrm{t}$ in 2011 . These capacities are planned to be used to incinerate mixed MSW but that does not exclude the incineration of other waste where technically possible (e.g. packaging waste). Table 1 shows the number of

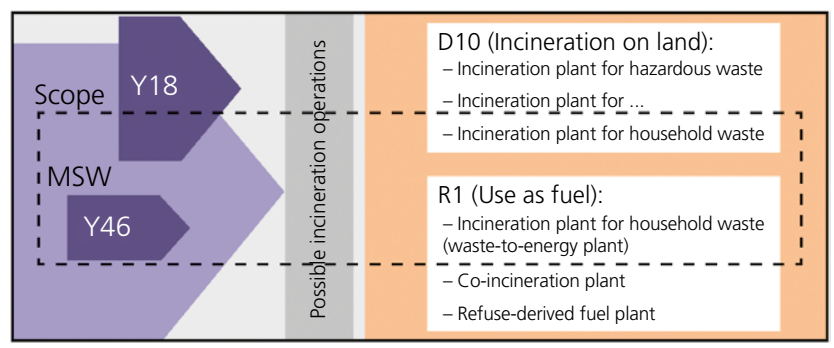

Figure 1. Data situation and scope of the study

\begin{tabular}{|c|c|c|}
\hline Country & $\begin{array}{c}\text { Number of } \\
\text { incineration plants }\end{array}$ & Capacity: t \\
\hline AT (Austria) & 11 & 2447199 \\
\hline BE (Belgium) & 15 & 2512000 \\
\hline BG (Bulgaria) & 0 & 0 \\
\hline CH (Switzerland) & 30 & 3682600 \\
\hline CZ (Czech Republic) & 3 & 646000 \\
\hline CY (Cyprus) & 0 & 0 \\
\hline DE (Germany) & 69 & 18829000 \\
\hline DK (Denmark) & 31 & 3777302 \\
\hline EE (Estonia) ${ }^{a}$ & 0 & 0 \\
\hline ES (Spain) & 11 & 2622000 \\
\hline $\mathrm{FI}\left(\right.$ Finland) ${ }^{\mathrm{a}}$ & 3 & 300000 \\
\hline FR (France) & 125 & 15559580 \\
\hline GR (Greece) & 0 & 0 \\
\hline HR (Croatia) ${ }^{a}$ & 0 & 0 \\
\hline HU (Hungary) & 1 & 420000 \\
\hline IE (Ireland) & 1 & 200000 \\
\hline IS (Iceland) & 8 & 32000 \\
\hline IT (Italy) & 51 & 5925647 \\
\hline LI (Liechtenstein) & 0 & 0 \\
\hline LT (Lithuania) & 0 & 0 \\
\hline LU (Luxembourg) & 1 & 150000 \\
\hline LV (Latvia) & 0 & 0 \\
\hline MT (Malta) & 0 & 0 \\
\hline NL (Netherlands) & 11 & 6740000 \\
\hline NO (Norway) & 15 & 1594000 \\
\hline PL (Poland) & 1 & 42000 \\
\hline PT (Portugal) & 3 & 1238000 \\
\hline RO (Romania) & 0 & 0 \\
\hline SE (Sweden) ${ }^{a}$ & 33 & 4792000 \\
\hline SI (Slovenia) & 0 & 0 \\
\hline SK (Slovakia) & 2 & 215000 \\
\hline UK (United Kingdom) ${ }^{a}$ & 25 & 5705700 \\
\hline
\end{tabular}

${ }^{a}$ Countries that have planned or built (additional) capacities after 2011

Table 1. Country-specific number and capacity of incineration plants for mixed MSW in 2011; the specific sources of the single incineration capacities can be found in the underlying study (Wilts and von Gries, 2014)

plants and capacity for each country. Countries that have planned or built (additional) capacities after 2011 are indicated in the table.

In some countries, very large waste-to-energy plants are common, while in other countries smaller plants are more common. Germany and France have the largest capacities for MSW incineration. Although Germany has a higher capacity 
than France, France has the largest number of plants (125). While researching incineration capacities in the EU in 2011, information about planned or built capacities after 2011 became available and Table 2 provides a tentative list of plants that have been built or planned since 2011. Although the list is incomplete, it is clear that the incineration capacities have a tendency towards further increases.

Figure 2 shows the spatial distribution of all 450 waste incineration plants in the EEA countries and the incineration capacity of the entire country per year and inhabitant. The figure shows the differences in MSW incineration capacity per capita across the EEA member countries. Denmark has the highest per capita incineration capacity with over $550 \mathrm{~kg}$ per capita, followed by the Netherlands, Norway, Sweden and Switzerland with capacities of $300-550 \mathrm{~kg}$ per capita. The remaining countries are in the middle range, or have small capacities of less than $100 \mathrm{~kg}$ per capita; some countries had no MSW incineration capacity in 2011.

Another way to analyse the countries' respective incineration capacities is to compare those capacities to MSW generation. Figure 3 shows the relation between incineration capacities and the share of the generated MSW they are theoretically able to incinerate.

Most of the countries have an incineration capacity of less than a quarter of their generated MSW, which could be an indication of either high recycling rates or large parts of the waste going to landfill. Some countries in this group use mechanical-biological treatment plants as an alternative route to treating mixed MSW. However, these countries could also be exporting waste to countries with larger capacities (imports and exports are discussed in Section 3.2). Sweden and Denmark in particular have more capacity than the entire amount of MSW they generate, parts of which are treated in other waste management operations (e.g. material recovery). However, in cases of high capacities compared with generated MSW, the risk of competing with recycling needs to be managed.

\subsection{Import and export of waste for incineration}

In order to properly assess waste incineration capacities, one has to take into account the import and export of waste for incineration - a practice that has significantly increased over the last few years (Fischer, 2012). This makes the picture much more complex, especially when it comes to the availability and quality of data describing this particular type of waste flow (see Section 2).

Figure 4 aims to give an indication of which part of the capacities is filled with imports or how much waste is exported in relation to the country-specific capacity. It should be noted that exports and imports for the R1 operation can also include waste for RDF plants. While the Y46 waste stream in principle consists of mixed MSW from households, which is therefore usually treated in the aforementioned two incineration operations (D10 and R1), the Y18 waste stream may also consist of other waste not from municipal sources (see Section 2.1).

Figure 4 shows the gross exported and imported MSW flows for incineration (R1 and D10) in 2011. Only considering the Y46 waste flows, MSW exports from the UK, the Netherlands, Italy, Ireland, France and Finland constitute between less than $1 \%$ and up to $6 \%$ of their respective incineration capacities. Belgium, Luxembourg and Sweden require significant amounts

\begin{tabular}{llll}
\hline Country & Location & Capacity: t/year & Source \\
\hline Estonia & Tallinn & 220000 & Moora (2014) \\
Finland & Vantaa & 320000 & Nikander and Säynätkari (2014) \\
& Oulu & 120000 & Nikander and Säynätkari (2014) \\
& Vaasa & 160000 & Nikander and Säynätkari (2014) \\
& Rijhimäki 2 & 100000 & Nikander and Säynätkari (2014) \\
Croatia & Zagreb & 385000 & WtERT (2014) \\
Sweden & Nybro & 40000 & Avfall Sverige (2014) \\
& Sigtuna (Brista) & 240000 & Avfall Sverige (2014) \\
& Upplands-Bro (Högbytorp) & 250000 & Avfall Sverige (2014) \\
& Västeraås & 360000 & Avfall Sverige (2014) \\
UK & Ardley (Oxfordshire) & 300000 & Defra (2013) \\
& Plymouth (Devon) & 275000 & Defra (2013) \\
& St. Dennis (Cornwall) & 240000 & Defra (2013)
\end{tabular}

Table 2. Planned or built incineration capacities for mixed MSW after 2011 


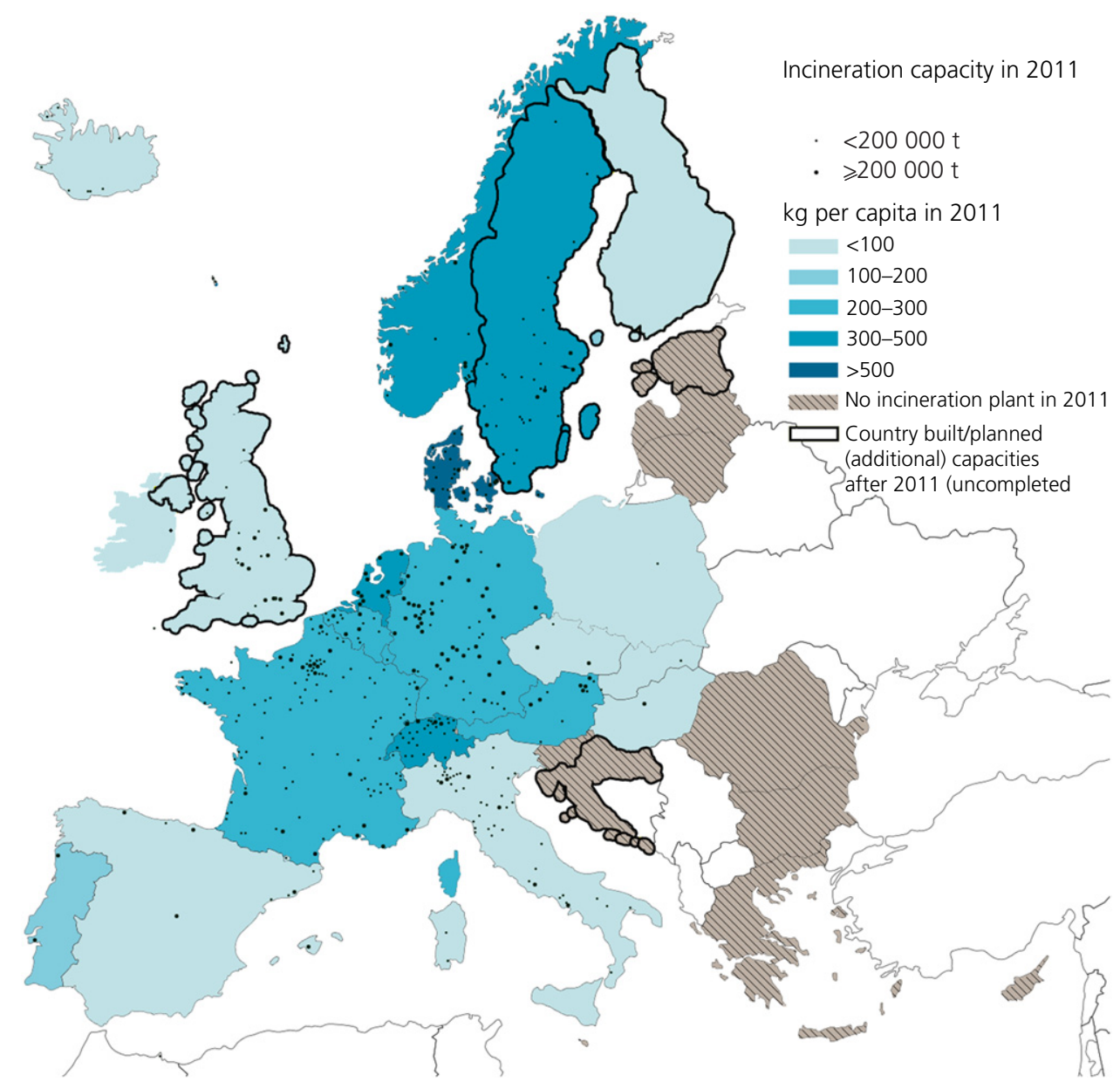

Figure 2. Incineration capacity for mixed MSW per capita and country as well as specific plant size, based on data in Table 1; the specific sources for capacities and locations of the single incineration plants can be found in the underlying study (Wilts and von Gries, 2014) of imports in order to keep their incineration capacities at sufficient utilisation rates. For Germany, imports of MSW for incineration are higher than the exports, which is why the net value is an import. Austria's net value is an export. The remaining countries do not declare any imports or exports of Y46 for incineration with a D10 or R1 classification.

The data in Figure 4 show that the picture of absolute imports and exports per incineration capacity changes drastically if we assume that $50 \%$ of the waste flows declared as Y18 are also sent to MSW incineration plants. For instance, in this case, Belgium turns from importer to net exporter. However, as the specific share of Y18 in the MSW flow for incineration is unknown, the data show the significance of including the import and export MSW flows per incineration capacity when determining national waste management over- and undercapacities.
Figure 5 shows the most important import and export flows of waste for incineration in 2011. The figure highlights the fact that these exports only refer to a limited number of countries - almost no Eastern European EEA members or southern European countries are included. It becomes clear that in Sweden (with regard to imports) and the UK (with regard to exports), waste incineration capacities have a high level of importance for the waste incineration market. Secondly, it becomes clear that the Netherlands and Germany have a mixture of imports and exports.

\section{Discussion}

\subsection{Waste incineration}

By far the best information is available for waste incineration plants and their capacities. For this study it was possible to identify capacity data for 450 waste incineration plants. The 


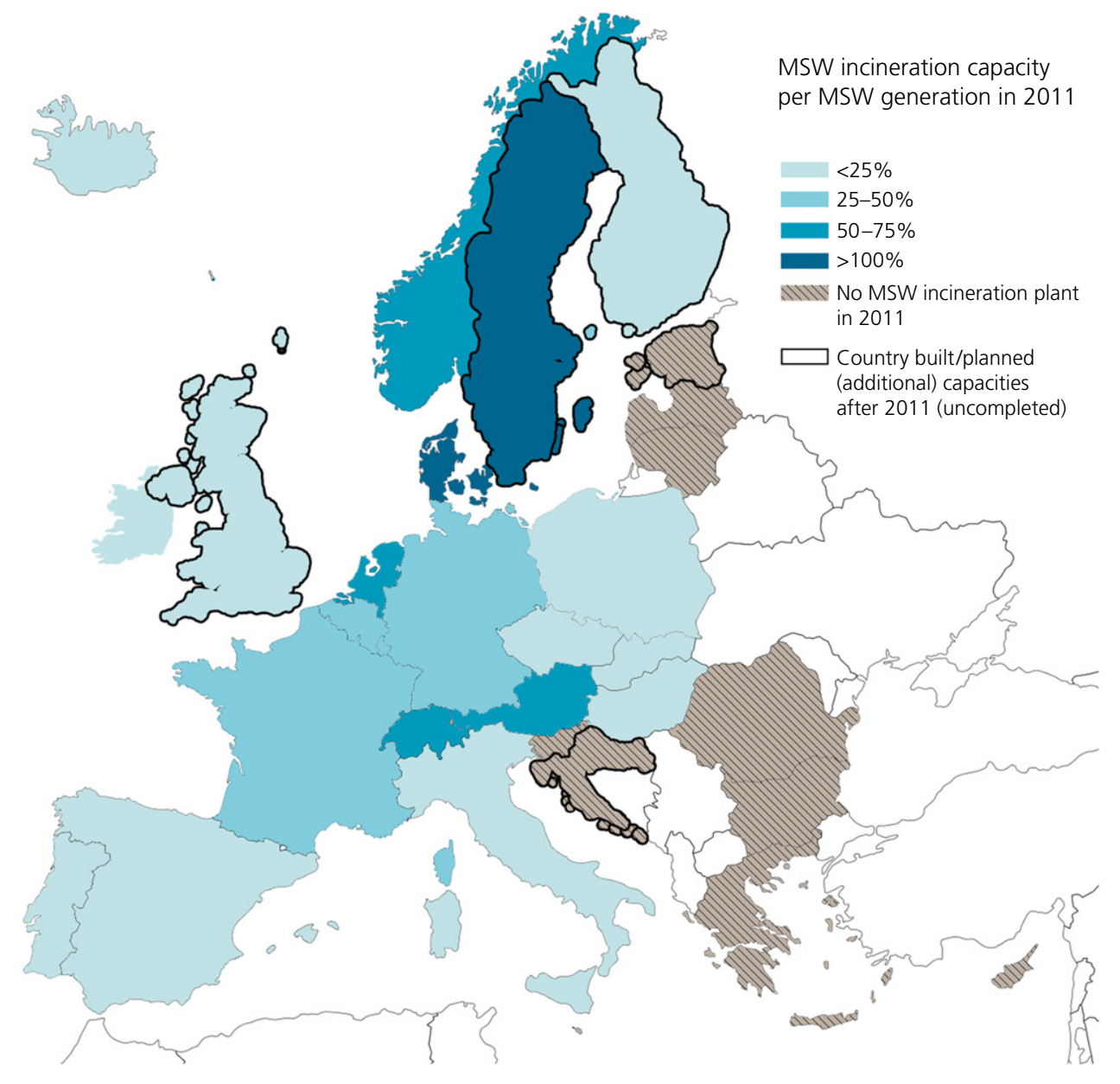

Figure 3. Incineration capacity per MSW generation, compiled by the authors according to data in Table 1 and Eurostat (2012a)

analysis of incineration capacity per capita or in relation to MSW generation shows the enormous differences between the different member states - ranging from 0 to more than $550 \mathrm{~kg}$ per capita of incineration capacity. In six of the 32 countries analysed in this study, the incineration capacities exceed 50\% of the annual waste generation, while in two of them the total amount of annually generated municipal waste is not enough to fill all the incineration plants (see Figure 3). These capacities might be used to incinerate waste from non-municipal sources and by using imports, and there are uncertainties surrounding the calculation of capacities. However, capacities far exceeding the amount of generated municipal waste indicate a potential trade-off between filling incineration capacities and achieving the 50\% recycling target of the 2008 WFD (Henkes, 2010), as well as the objectives of the EU's Seventh Environmental Action Programme to move towards a circular economy, to limit energy recovery to non-recyclable material and to reduce the generation of waste (EC, 2013b).
In general, the figures presented in this paper might allow the preliminary conclusion to be drawn that significant regional overcapacities for waste incineration exist in Europe. However, regarding the total aggregated level, additional investments in waste incineration capacity might be useful to divert additional waste streams from landfilling - optimally based on an integrated waste capacity planning procedure on a European level.

A key limitation in interpretation of the available data is the fact that the data do not give a complete overview of how much non-mixed MSW is incinerated in plants originally dedicated to mixed MSW, nor is it possible to define how much mixed MSW is incinerated in RDF plants or in co-incineration plants. In both cases the data for amounts are of course limited by technical requirements (e.g. quality requirements for the input, especially with regard to the calorific value). Nevertheless, the partial analysis offered in this report presents 


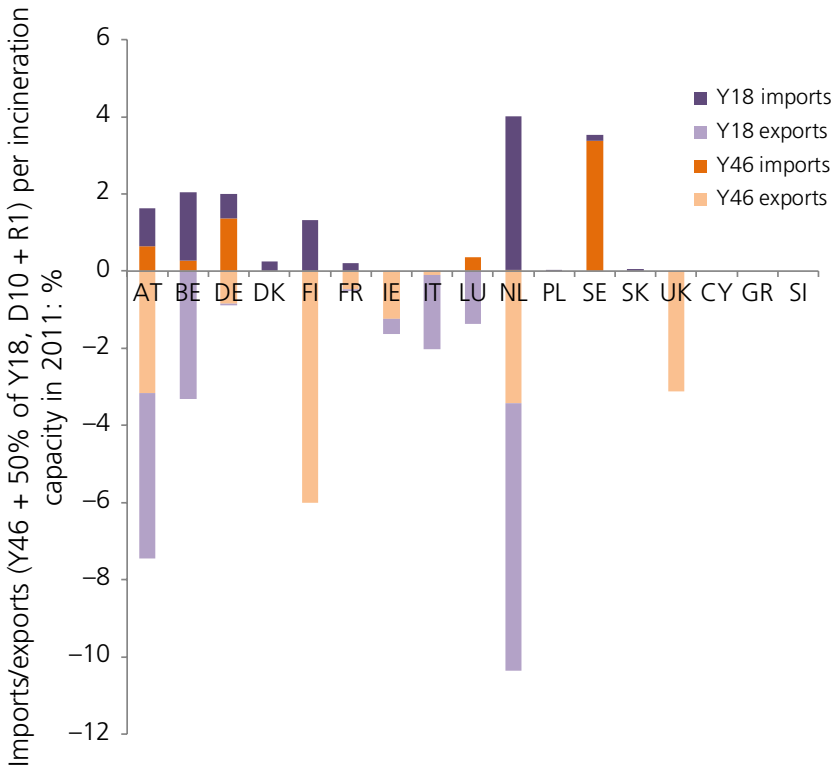

Figure 4. Gross imports and exports per incineration capacity in 2011. Note: CY, GR and SI do not have any incineration capacities other than through exports. Compiled by the authors according to Table 1 and Eurostat (2013); the specific numbers for the imports and exports can be found elsewhere (Wilts and von Gries, 2014)

a starting point for an assessment of the total European waste incineration market (see Section 5).

\subsection{Exports and imports for waste incineration}

In general, imports and exports of municipal waste for incineration can give an indication of regional over- and undercapacities. At first sight, the comparison with waste incineration capacities seems to indicate that 'waste tourism' or 'vacuum cleaner effects' (EC, 2013a) of incineration overcapacities at least for mixed MSW are only of limited significance. However, the import and export data used for this analysis (Y46, Y18) might not tell the full story.

The inconsistencies between reported exports and imports of these waste streams seriously hamper analysis. Nevertheless, there are several waste flows that can clearly be linked to differences in waste treatment capacities in relation to waste generation, for example the high imports of waste for incineration in Sweden and at the same time the much higher share of incineration capacity than the whole of their generated MSW amount. A key element of uncertainty is how much municipal waste or RDF from municipal sources is exported and imported and labelled as Y18. If it is assumed that $50 \%$ of Y18 waste imported or exported for incineration is from municipal sources (and this assumption is arbitrary as no data are available regarding the share of Y18 derived from municipal waste), the picture changes dramatically. Under this assumption, Sweden would have filled more than $10 \%$ of its national incineration capacity with imported waste in 2011, and the Netherlands would be by far the most important exporter of waste for incineration.

\subsection{Clarifying waste prevention potentials}

The actual need for waste incineration capacity is also clearly linked to waste prevention (defined as being at the top of the waste hierarchy) - something that, on paper, obligates all waste infrastructure planning to focus on the avoidance of waste generation in the first place. Accounting for these activities, a question soon arises: What prevention effects can realistically be achieved by applying the measures described in the waste prevention programme of the federal government or other member states? The generation of waste is to a great extent considered unavoidable and thus the potential of waste prevention measures is neglected (Wilts et al., 2013). A current study on behalf of the EC estimates waste prevention potential at $4 \%$ if all waste legislation guidelines were adopted by 2020 (BIO IS, 2011b). But why does this result in such a low number that makes it seem that waste prevention is far from a top priority in the waste hierarchy? In this regard, the study by the BIO Intelligence Service (BIO IS, 2011b) states the following

Experience with cleaner production centres in Germany has shown that some $8 \%$ of waste generation can be prevented by supporting the enterprises through audit, consulting and financing schemes. It is assumed that this $8 \%$ are a typical waste prevention potential for all waste types. It is further assumed that half of this potential can be activated by the new waste prevention measures till 2020 .

Meanwhile, a variety of studies exist for waste streams such as packaging, food waste, bulky waste and production waste. On the one hand, these present information about the potential of waste prevention and on the other also suggest specific measures that could be associated with particular forms of successful prevention (Ekvall et al., 2010; Gentil et al., 2011; Wilts and Rademacher, 2014). The analysis of such pilot projects and innovative initiatives makes it clear that there are still high levels of unexploited potential in the prevention of waste under existing technical and institutional circumstances. Even for the automobile sector, which is generally regarded to be very cost-sensitive, practitioners deem there to be a realistic saving potential of more than $10 \%$ of used materials (Schroter et al., 2011), which could also become visible in the waste prevention measures adopted by business. The area of food waste also shows that simple measures could already result in more than 10\% savings (Wilts and Rademacher, 2014). Systemic approaches such as the 'share economy' (Heinrichs and Grunenberg, 2013) or the 'leasing society' (Fischer et al., $2012 b$ ) are frontrunners of a fundamental change in consumption patterns that suggests that a new relationship between 


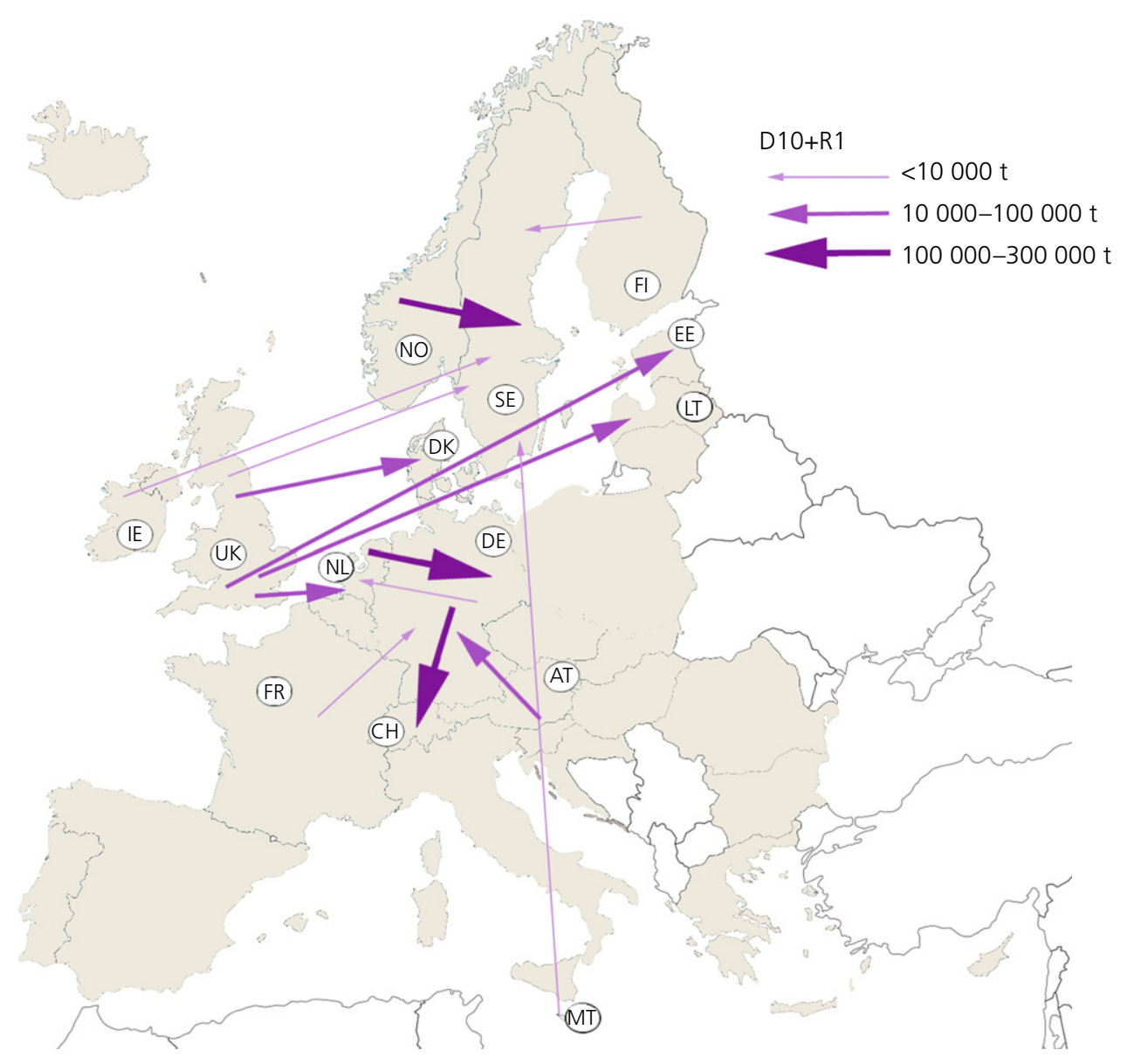

Figure 5. Largest Y46 waste flows for incineration in 2011, compiled by the authors from Eurostat (2013); the specific numbers for the imports and exports can be found elsewhere (Wilts and von Gries, 2014)

wealth and products has the potential for making a realistic reduction of at least half of all generated waste.

\section{Conclusions for future infrastructure planning}

The empirical results underline the need to define the role of waste incineration in a circular economy. Right now, no common understanding exists as to how much capacity might be needed to treat waste as a resource, while obviously EU member states each follow different concepts - leading to regional overcapacities and increased imports/exports of waste for incineration (especially with regard to RDF) (Defra, 2014; Olofsson et al., 2005). From a policy perspective there seems to be a need for innovative planning procedures that might help to avoid such overcapacities through an integrated assessment of recycling and prevention potential. The basic idea should be to avoid cost-intensive path dependencies and focus on a comprehensive network structure that allows waste treatment capacities to keep pace with dynamic economic developments.

The current planning of the waste infrastructure in Europe is obviously based on a supply-side approach that aims to offer sufficient waste treatment - and especially incineration capacities in order to get rid of all waste generated in specific spatial contexts. In Germany, with its strong focus on waste incineration, one of the leading environmental politicians expressed it as: 'In the end waste policy is all about where to burn our municipal waste' (Wilts, 2014). So far, this conventional infrastructure planning approach has received particular criticism in the transportation sector because it completely neglects all attempts to influence the demand side. Instead of 
asking which urban infrastructures might be necessary for planned or postulated future demand, Moss (2011) points out that there is an urgent need to plan how the demand can be reduced or how societal needs can be fulfilled within more environmentally friendly systems. The current focus on ensuring safe disposal needs to be amended by using demand-side approaches that include consumers and industries as producers of waste (Neumann, 2011). In this way, a stronger linking of the flows of specific materials could be realised with significant potential for reducing the need for disposal and incineration capacities.

Further research will be needed to analyse the long-term effects of specific innovations, processes or technologies with regard to their waste prevention potential and the consequences of the need for waste incineration capacity. In particular, an integrated assessment of environmental and ecologic saving potentials will be necessary in order to trigger further eco-innovations and to allow an efficient allocation of benefits between the different actors in the value chain. Such transparency is the starting point for integrated waste management planning that goes beyond supply-/end-of-pipe-oriented waste management planning and thus avoids obstacles such as overcapacities in incineration on the road to a 'circular economy'.

\section{REFERENCES}

Alwast H (2014) Abfallwirtschaft im Gleichgewicht? Entwicklung von Restabfallmengen und die künftig notwendigen Behandlungskapazitäten in Deutschland. See http://www. prognos.com/uploads/tx_atwpubdb/140508_HAL_IFATVortrag.pdf (accessed 12/08/2014) (in German).

Avfall Sverige (2014) Kapacitetsutredning 2013 Avfallsfürbränning till år 2020. See http://www.avfallsverige. se/fileadmin/uploads/Rapporter/F $\% \mathrm{C} 3 \% \mathrm{~B} 6 \mathrm{rbr} \% \mathrm{C} 3 \%$ A4nning/E2013-04.pdf (accessed 06/07/2014) (in Swedish).

Basel Convention (2011) National Reporting Archives. See http://www.basel.int/Countries/NationalReporting/ NationalReportingArchives/tabid/2315/Default.aspx (accessed 07/10/2013).

BIO IS (BIO Intelligence Service) (2011a) Study on Coherence of Waste Legislation. BIO IS, Paris, France, Final report prepared for the European Commission (DG ENV).

BIO IS (2011b) Implementing EU Waste Legislation for Green Growth. BIO IS, Paris, France, Final report prepared for European Commission (DG ENV).

BiPRO (Beratungsgesellschaft für integrierte Problemlösungen) (2012) Screening of Waste Management Performance of EU Member States. BiPRO, Munich, Germany, Report submitted under the EC project 'Support to Member States in improving waste management based on assessment of Member States' performance', prepared for the European Commission (DG ENV).
CEWEP (Confederation of European Waste-to-Energy Plants) (2010) Country Reports on Waste Management. See http:/l www.cewep.eu/information/data/subdir/442._Country_ Report_on_Waste_Management.html (accessed 07/10/ 2013).

Defra (Department for Environment, Food \& Rural Affairs) (2013) Incineration of Municipal Solid Waste. See https:/l www.gov.uk/government/uploads/system/uploads/ attachment_data/file/181825/pb13889-incinerationmunicipal-waste.pdf (accessed 06/07/2014).

Defra (2014) Energy from Waste - A Guide to the Debate. See https://www.gov.uk/government/uploads/system/uploads/ attachment_data/file/284612/pb14130-energy-waste-201402. pdf (accessed 12/08/2014).

Dehoust G, Harthan RO, Stahl H et al. (2014) Beitrag der Kreislaufwirtschaft zur EnergiewendeKlimaschutzpotenziale auch unter geänderten Rahmenbedingungen optimal nutzen. Öko-Institut, Berlin, Germany (in German).

Döing M and Loenicker J (2013) Markt für thermische Abfallverwertung wächst unterschiedlich. Müll und Abfall 12(2013): 650-654 (in German).

EC (European Commission) (2008) Directive 2008/98/EC of the European Parliament and of the Council of 19 November 2008 on waste and repealing certain Directives. Official Journal of the European Union L312/3.

EC (2011) Roadmap to a Resource Efficient Europe. COM (2011) 571 final.

EC (2013a) Green Paper - On a European Strategy on Plastic Waste in the Environment. COM (2013) 123 final.

EC (2013b) Decision No 1386/2013/EU of the European Parliament and of the Council of 20 November 2013 on a General Union Environment Action Programme to 2020 'Living well, within the limits of our planet'. Official Journal of the European Union L354/171.

EEA (European Environment Agency) (2013a) Managing Municipal Solid Waste - A Review of Achievements in 32 European Countries. EEA, Copenhagen, Denmark, EEA report 2/2013.

EEA (2013b) Municipal Waste Management - Country Reports. See http://www.eea.europa.eu/publications/managingmunicipal-solid-waste (accessed 07/10/2013).

Ekvall T, Sahlin J and Sundberg J (2010) Effects of Policy Instruments on Waste Intensities. Swedish Environmental Research Institute, Stockholm, Sweden, Report B1939.

EMAF (Ellen MacArthur Foundation) (2012) Towards the Circular Economy - Economic and Business Rationale for an accelerated Transition. EMAF, Cowes, UK, Report 1/2012.

Eurostat (2012a) Environmental Data Centre on Waste. Management - Generation. See http://epp.eurostat.ec. europa.eu/portal/page/portal/waste/waste_generation_ management/generation (accessed 20/12/2013). 
Eurostat (2012b) Environmental Data Centre on Waste. Management - Incineration. See http://epp.eurostat.ec. europa.eu/portal/page/portal/waste/waste_generation_ management/management/incineration (accessed 13/01/ 2014)

Eurostat (2013) Environmental Data Centre on Waste Transboundary Waste Shipments. See http://epp.eurostat.ec. europa.eu/portal/page/portal/waste/transboundary_waste_ shipments (accessed 13/09/2013).

Fischer C (2012) Transboundary Shipments of Waste - Data Checks and Data Based on the European Waste List ( $E W L$ ). See http://www.unece.org/fileadmin/DAM/stats/ documents/ece/ces/ge.33/2012/mtg1/Session_4. _Transboundary_shipments_data_based_on_EWL_-Christian_Fischer_European_Topic_Center.pdf (accessed 06/10/2013).

Fischer C, Junker H, Mazzanti M et al. (2012a) Transboundary Shipments of Waste in the European Union - Reflections on Data, Environmental Impacts and Drivers. European Topic Centre on Sustainable Consumption and Production (ETC/SCP), Copenhagen, Denmark, ETC/SCP working paper $2 / 2012$.

Fischer S, Steger S, Jordan ND, O'Brien M and Schepelmann P (2012b) Leasing Society. European Parliament, Brussels, Belgium.

Gentil EC, Gallo D and Christensen TH (2011) Environmental evaluation of municipal waste prevention. Waste Management 31(12): 2371-2379.

Heinrichs H and Grunenberg H (2013) Sharing Economy: Towards a New Culture of Consumption? Centre for Sustainability Management, Luneburg, Germany.

Henkes W (2010) Kirchturmdenken. Recycling Magazin 8(2010): 24-25, (in German).

ISWA (International Solid Waste Association) (2012) Waste-toEnergy State-of-the-Art Report - Statistics 6th Edition. ISWA, Copenhagen, Denmark.

Jafra Sora M (2013) Incineration Overcapacity and Waste Shipping in Europe: The End of the Proximity Principle? See http://zazemiata.org/v1/fileadmin/content/otpaduci/ docs/Overcapacity_report_2013.pdf (accessed 06/10/2013).

Monstadt J (2009) Conceptualizing the political ecology of urban infrastructures: insights from technology and urban studies. Environment and Planning 41(8): 1924-1942.

Monstadt J, Schmidt M and Wilts H (2012) Regionale Zusammenarbeit in der Ver- und Entsorgung des Rhein-Main-Gebiets. In Die diskutierte Region: Probleme und Planungsansätze der Metropolregion Rhein-Main (Monstadt J, Zimmermann K, Robischon T and Schönig B (eds)). Campus Verlag, Frankfurt, Germany, pp. 185-210 (in German).

Moora H (2014) Waste Management in Estonia. See http://www.recobaltic21.net/downloads/Public/ Conferences/Baltic $\% 20$ Waste $\% 20$ Management $\%$
20Seminar\%202012/06_harri_moora_wm_in_estonia.pdf (accessed 06/07/2014).

Moss T (2011) Planung technischer Infrastruktur für die Raumentwicklung: Ansprüche und Herausforderungen in Deutschland. In Zukunftsfähige Infrastruktur und Raumentwicklung: Handlungserfordernisse für Ver- und Entsorgungssysteme (Tietz HP and Hühner T (eds)). Forschungs- und Sitzungsberichte der ARL, Hannover, Germany, pp. 73-94 (in German).

Neumann M (2011) Infrastructure planning for sustainable cities. Geographica Helvetica 15(2): 100-107.

Nikander H and Säynätkari T (2014) Waste incineration capacities in Finland. E-mail message from the Finnish Environment Institute, 5th March. European Environment Agency, Copenhagen, Denmark.

O'Donovan E and Collins ML (2011) An Economic Evaluation of Incineration as a Residual Municipal Solid Waste Management Option in Ireland. Department of Economics, Trinity College, Dublin, Ireland, TEP working paper 1811.

Olofsson M, Sahlin J, Ekvall T and Sundberg J (2005) Driving forces for import of waste for energy recovery in Sweden. Waste Management \& Research 23(1): 3-12.

Richers U (2010) Abfallverbrennung in Deutschland Entwicklungen und Kapazitäten. Karlsruhe Institute of Technology, Karlsruhe, Germany, KIT scientific report 7560 (in German).

Sahlin J, Ekvall T, Bisaillon M and Sundberg J (2007) Introduction of a waste incineration tax: effects on the Swedish waste flows. Resources, Conservation and Recycling 51(4): 827-846.

Scheelhaase T, Braungart M and Semisch C (2008) Zukunft verbrennen? Von der Abfallverbrennung hin zur Wertstoffschöpfung nach Cradle to Cradle - Auswirkungen von 'Ersatzbrennstoff-Verbrennungsanlagen' auf die Entwicklung biologischer und technischer Nährstoffkreisläufe. EPEA Internationale Umweltforschung, Hamburg, Germany (in German).

Schroter M, Lerch C and Jäger A (2011) Material Efficiency in Production: Savings and Dissemination of Concepts for Saving Materials in Manufacturing. Fraunhofer Institute for Systems and Innovation Research (ISI), Karlsruhe, Germany, Final report to the Federal Ministry of Economics and Technology (BMWi).

Star SL (1999) The ethnography of infrastructure. American Behavioral Scientist 43(3): 377-391.

Wilts H (2013) Abfallwirtschaftsplanung - lokal bis global. Raumplanung 166(2013): 35-38 (in German).

Wilts H (2014) Transitionsprozesse in Metropolregionen am Beispiel der kommunalen Abfallwirtschaft. Dissertation, TU Darmstadt, Institut IWAR, Darmstadt, Germany (in German).

Wilts H and Rademacher B (2014) Potentials and evaluation of prevention measures - a case study 
for Germany. International Journal of Waste

Resources 137(4), http://dx.doi.org/10.4303/2252-

5211.1000137.

Wilts H and von Gries N (2014) Municipal Solid Waste Management Capacities in Europe - Desktop Study. European Topic Centre on Sustainable Consumption and Production (ETC/SCP), Copenhagen, Denmark, ETC/SCP working paper 8/2014.
Wilts H, Dehoust G, Jepsen D and Knappe F (2013)

Eco-innovations for waste prevention - best practices, drivers and barriers. Science of the Total Environment 461(2013): 823-829.

WtERT (Waste-to-Energy Research and Technology Council) (2014) Zagreb will nevertheless get a WtE plant. See http://www.wtert.eu/Default.asp?Menue $=18 \&$ NewsPPV $=$ 8613 (accessed 06/07/2014).

\section{WHAT DO YOU THINK?}

To discuss this paper, please email up to 500 words to the editor at journals@ice.org.uk. Your contribution will be forwarded to the author(s) for a reply and, if considered appropriate by the editorial panel, will be published as discussion in a future issue of the journal.

Proceedings journals rely entirely on contributions sent in by civil engineering professionals, academics and students. Papers should be 2000-5000 words long (briefing papers should be 1000-2000 words long), with adequate illustrations and references. You can submit your paper online via www.icevirtuallibrary.com/content/journals, where you will also find detailed author guidelines. 